\title{
Local Wisdoms Based-English Varieties: A Study on the Development of ICT-Based Learning Materials-Development Model
}

\author{
Dedi Aprianto
}

Universitas Bumigora, Indonesia

Correspondence: Dedi Aprianto, Universitas Bumigora, Indonesia. e-mail: dediaprianto44@gmail.com

Submitted: Desember 18, 2019

DOI: $10.29408 /$ veles.v4i1.1750
Revised: March 12, 2020

URL: http://dx.doi.org/10.29408/veles.v4i1.1750

Accepted: March 16, 2020

Abstract

English with global phenomena has the consequent emergence of English varieties. The existence of this variety as a result of the diversity of speakers who have mother tongue (L1) differs geographically and demographically. These varieties occur minimally in the aspects of the lexicon, grammar, and phonology. On the other hand, aspects of local wisdoms (indigenous wisdoms) have the potential to produce linguistic elements. This paper is oriented to the English variety model based on local wisdoms in the development of information technology-assisted learning materials for secondary schools. In the framework of implementing the 2013 curriculum effectively, this elaboration refers to regulations of Permendikbud on Curriculum 2013, Basic Competencies of Curriculum 2013, Review of Curriculum Policy in Language Subjects, Main Thoughts and Recommendations on English Curriculum 2013, and Analysis of Content Standard of English subject for junior high school and senior high school. This is done by looking at the diversity of local wisdoms through translation from the first language (Indonesian/regional) to the target language (English). In the process of language translation, the theory that is referred to is the theory of MeaningBased Translation which is about the features and relations of semantic components as characteristics possessed by all languages.

Keywords: English Varieties, Local Wisdoms, Learning, Information Technology (IT)

\section{Introduction}

This study includes the development of English language learning materials based on local wisdoms to be applied in the secondary schools (SMP) becoming model of English varieties with the use of information technology in the Lombok island, West Nusa Tenggara. This idea is a consequence of globalization and dynamism of English both geographically and demographically. And even academically and professionally that has been politicized into English for special purposes (ESP) according to the scientific fields. In the context of this ESP, the author has also received a grant research from the Director General of the Ministry of Education and Culture 2013 in a decentralized research scheme, which examines the problem of learning English with a case study in the field of information and communication technology (ICT) for the Department of Information Technology. 
The phenomenon of local wisdoms based English varieties contextually is to examine the geographical and demographic potentials in particular, through the intervention and creativity of thought into meaningful learning outputs for future sustainability. This idea is in line with "Teaching and Learning for a Sustainable Future (UNESCO, 2001: 2)". Indigenous knowledge is the local knowledge that is unique to a culture or society. Other related terms in this view include local knowledge, folk knowledge, people's knowledge, traditional wisdoms, or traditional sciences. Next the knowledge is passed from generation to generation, usually by words and cultural rituals, and has been the basis for agriculture, food preparation, healthcare, education, conservation, and the wide range of other activities which sustain societies in many parts of the world. The statement specifically emphasized that the indigenous knowledge is stored in cultures in various forms, such as traditions, customs, folk stories, folk songs, folk dramas, legends, proverbs, myths, etc. The use of these cultural items as resources in schools can be very effective in bringing indigenous knowledge alive for the students (page 39). In essence, local wisdom as a source of knowledge that is unique to a culture or society that includes local knowledge contained in various cultures can be used as a source of learning in the educational process that is very effective for generations from one generation to the next generation through local living wisdoms for English students.

The elements of local wisdoms in the context of Lombok Island, West Nusa Tenggara, would potentially be the emergence of findings of linguistic phenomena as linguistic elements including in English varieties after going through the process of transliteration according to linguistic rules. English varieties as a consequence of globalization of English are identified as one of the key issues in the conflict between global and local arising in relation to the notion of plurality of English 'World Englishness' (Kachru and Nelson in Mahboob and Tilakaratna, 2012: 9) which allows English varieties are known to be a cross cultural and global contextualization of English in multiple sounds as being cross-cultural and global contextualization of the English language in multiple voices, because English is now experiencing a shift from a language that was used primarily by native speakers of intranational and communal purposes to become an international tool classified as Lingua Franca communication (Jenkins, 2003b; Kirkpatrick, 2007, Jindapitaks and Teo, 2013: 1).

The status and function of English in Indonesia, via a review of a number of key factors conveyed by Allan Lauder (2008), he suggested that English is now essential for development. The society should be given every opportunity to learn English. One way to do this is by giving English a new status. At this way, in the context of local socio-cultural values, Lauder (page 9) encouraged the writers and designers of local materials, as stated that it is an extremely good idea to encourage local writers to produce locally relevant EFL materials, but the almost total absence of written materials by native speakers is an anomaly at best. Responding to this idea, in terms of involving native speakers in the process of preparing related material, it can be justified in the context of perfection. On the other hand in line with a policy, a set of the standards of development to improve English Language Learning (ELL) in one context cannot be applied to other contexts (Mahboob and Tilakaratna, 2012: 2), due to the socio-cultural, political, economic uniqueness and historical aspects of each countries or circumstances need to be taken into account when making language policies between English 
Language Learning programs and the accuracy of standards as illustrated in form of models as follows:

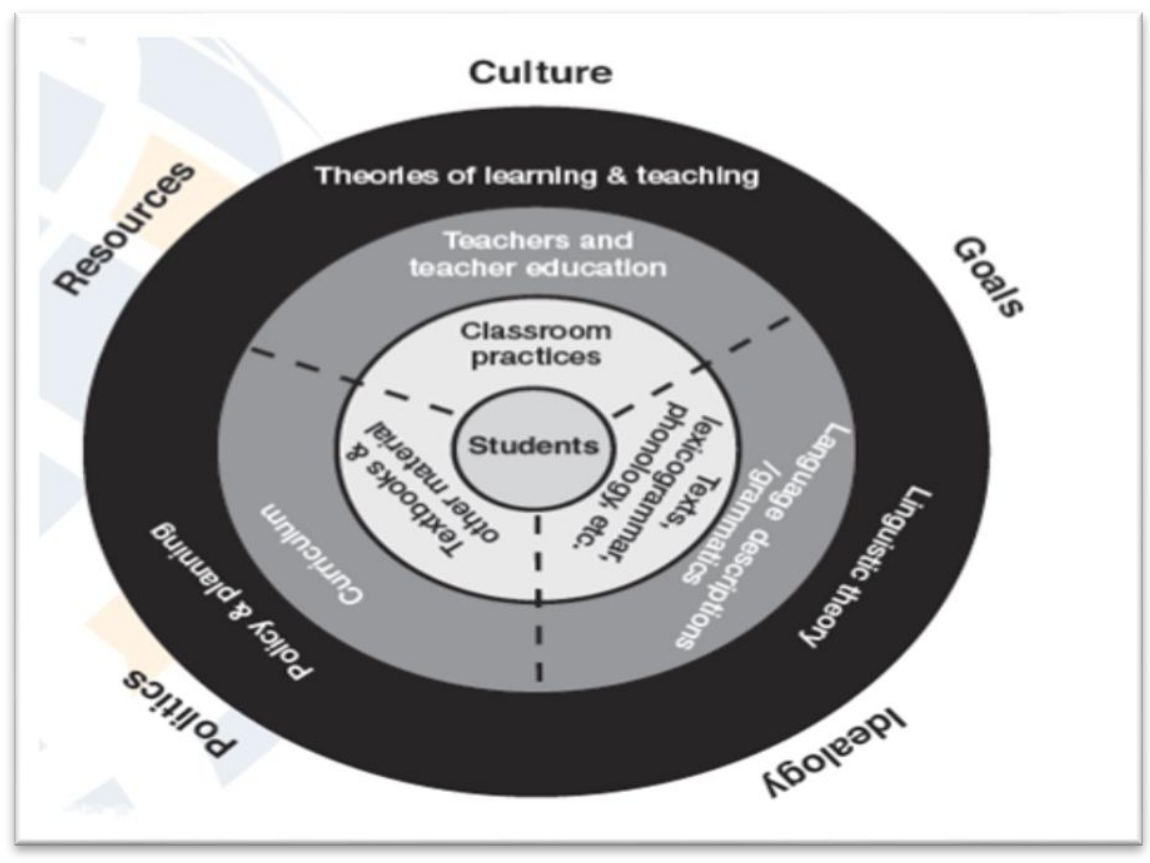

Figure 1: Factors affecting in Language Learning; adapted in Factors that shape students' Learning Experiences in an ELT Classroom (Mahboob \& Tilakaratna, 2012).

Furthermore, according to Mahboob and Tilakaratna (2012), the task of local consultants and research development executors in various countries is to be adjusted to determine what an effective form to implement is in the scope of the country concerned. The idea developed by them is as a result of the emergence of the globalization demands and the local interests of the society who experience the main impact of English learning.

The description of the phenomenon distribution which is presented as a communication device is not only the interaction between native speakers with non-native speakers, but also for the purpose of meaningful interactions between those who are not native speakers (Crystal, 1997; Graddol, 2007, Jindapitak and Teo, 2013: 1). Related to English as Lingua Franca. Seidlhofer (2011: 7) defines that anyone who uses English among the speakers who come from different mother tongue or different first language (Cogo, 2015: 1), or the use of English as a common means of communication across communities and territorial boundaries (Vettorel, 2015: 1).

The term plurality of English World Englishness (Diversity of World English) is further formed by the belief that people have the right to own and use the language they intend to in their own standards (Seidlhofer, 2007). Bhatt (2001) provides a definition of plurality of English that refers to variations in English that are used in different sociolinguistic contexts. This is relevant to the definition of Jenkins (2006), that plurality of English is the native diversity which is dependent to their local contextual use.

To resolve the disputes as well as the problems which are faced caused by the globalization, English teaching materials need to be localized, domesticated and regionalized 
to the local needs of communities for considering their identity, individuality, and values. In this extreme sense, an English localization leads to the nativisation or indigenization of a kind of adaptation that occurs when a language is used in different contexts and adjusts to its needs by means of distinctive varieties that arise after a period of time (Richards \& Schmidt, 2002, Shakouri and Espandiari 2015: 3-4). This is the basis for the emergence of globalization as opposed to globalization of English textbooks by combining both global and local values.

These are related indeed to curriculum, material and evaluation of English Language Learning (ELL) issues. It is suggested that local educators need to play a role in the ownership in teaching English as an international language and appropriate pedagogy design (learning design) in accordance with local culture learning (Mckay, 2002, Rattanaphumma, 2007). As mentioned above, attitudes towards English should be taken into account both local norms and English varieties. The concepts, attitudes and beliefs that underline the English learning curriculum should reflect the practicality and usefulness of teaching English. Hicks explains how high and clear the curriculum values are:

First, it is related to the problem of global language studies, but it is equally important that learners learn more about their own local language and use their own language through others, secondly, the context of language, topics and issues, must and can be included in real terms in the local world of learners, not in their global world. Such curriculum and methodology help learners feel good both at the local and global community level (Hicks, 2000: 3, Rattaphumma, 2007).

English materials and textbooks used in learning English as a Foreign Language class should also carefully be considered. As an international language, English does not only belong to one country or particular culture (McKay, 2003, Rattanaphumma, 2007), moreover English material are needed to make interesting, relevant, and meaningful for the learners, because cultural backgrounds both help and create mutual understanding among English users. There are three types of cultural information as the English material sources, as suggested by Cortazzi and Jin (1999), Mckay (2003), Rattanaphumma (2007), as follows:

1) Material sourcing from culture that describes the culture of the learners themselves as content;

2) Cultural target materials that use the culture of a country where English is spoken as the first language;

3) International cultural target materials that use high cultural varieties in speaking countries and not English speakers throughout the world.

Local teachers are now in so good position to contribute to teach English in the scope of the expanding circle using English as a Foreign Language (EFL). They should be aware of the role and function of English as an international language and develop aspects of pedagogy that are appropriate for their students regarding curriculum, materials, textbooks, and evaluation. (Rattanaphumma, 2007: 18-20). In this context also, the issue of English varieties in ASEAN countries gradually becomes a concern and discussion among professionals and scholars (Bolton, 2003; Kachru, 2005, Fang, 2012: 1). Thereby, local wisdoms become a 
strategic potential source for mediating global and local issues to expose the potentials of linguistics to treasury of science and can contribute to English learning.

\section{English Language and Local Wisdoms}

According to the index target and the cultural capital mapping by region (see diagram of themes and research topics in the field of Social Humanities-Cultural Arts-Education, and table of research integration in the field of Social Humanities-Cultural Arts-Education, pp. 8284 RIRN Documents 2015-2045 version 3.5.2, Compilation 20016), which includes language and other related elements, are the elements of local wisdoms (indigenous studies) which is projected to be a buffer towards the global village polarization. In this context, the variety of local wisdoms become a kind of important black box to be revealed and has the potential to become English learning materials, after going through the process of linguistics, which follows language rules as well as applied linguistics (translation). In this case, the diversity of local wisdoms presented in various documents and languages (regional languages and Indonesian language) will be used as a source of learning English after going through the process of linguistically translating into English. The scheme of national research concepts in the social humanities field to 2019, which includes local wisdoms as one of the ten national research priorities in the RIRN (Rencana Induk Riset Nasional) is as follows:

The Master Plan of National Research 2017-2045

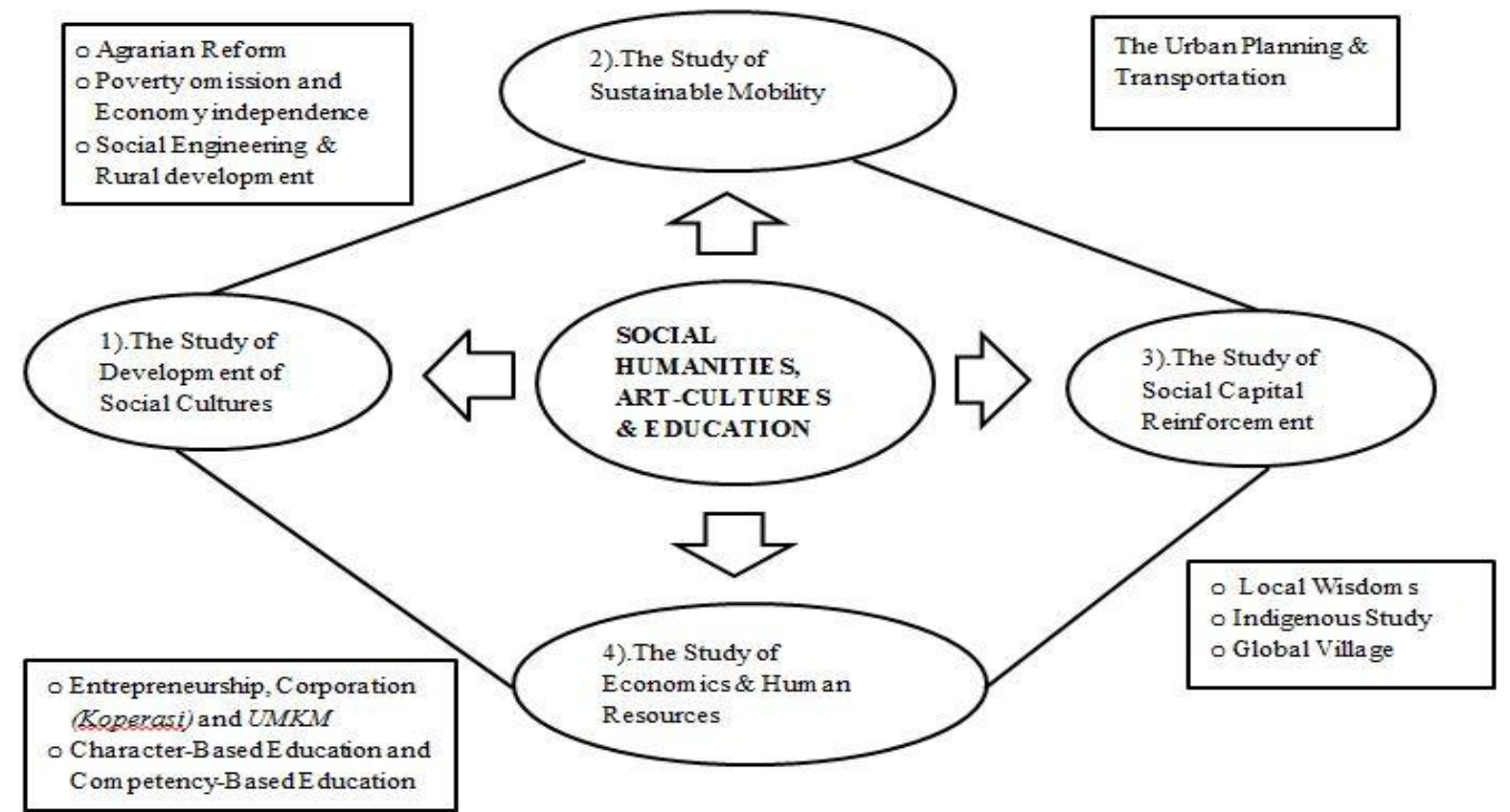

Figure 2: Rencana Induk Riset Nasional (RIRN) from 2017 to 2045

Local wisdom is one of the elements of culture (Geertz, 1973, Wagiran, 2011) stating local wisdom is part of culture, and local wisdom is an element of traditional culture that has deep roots in human's life and community's related to human resources, culture, economy, security and legal standing (law). Local wisdom can be seen as a tradition related to agricultural activities, animal husbandry, building or house construction, etc. Even the 
Wagiran (p. 4) further elaborates regarding local wisdom as follows: in the cultural sphere, the physical dimensions of local wisdoms include aspects: customary ceremonies, cultural heritage, natural tourism, traditional transportation, traditional games, cultural infrastructure, traditional clothing, cultural heritage, museums, cultural institutions, arts, cultural villages, arts and crafts, Folklore, Children's games, and Wayang (leather animation). Another source of local wisdoms can be Javanese life circle which includes: Tingkeban ceremony, birth ceremony, circumcision, marriage, and death.

In line with the various classifications of local wisdom in the context of Lombok island's potentials and its natural resources, as included in the local wisdom mentioned above, will contribute to the treasury of knowledge, especially in enriching the reference or materials of English language learning after going through a process of transliteration in linguistics, especially students of secondary schools in local contexts. This indicates that the importance of the initiation of academicians and teachers through a scientific works or a scientific paper to develop and empower the various potentials to be contributed, so that the concerning group of people can recognize and internalize the characteristics of local wisdoms expressed in English, both in the learning process and outside the learning context. Characteristics of local wisdoms as well as being a variety or diversity of English, as stated by Seargean and Swann (2012: 229) that the potential for the diversity of use of a syllable-timed rhythm, simplified sentence construction, avoidance of idioms, and colloquial vocabulary, slower rate of speech, clearer patterns of articulation that is related to the time rhythm of a sound, simplifying sentence structure, avoiding the use of idioms, daily vocabulary, slower speech, and clarifier of articulation patterns.

Thus, it cannot denied that everything around the students' environment can be as a relevant sources of language learning, including that which comes from local wisdoms, as stated by Ignas (2012) in the Canadian Journal of Native Education that Science is not found in textbooks-materials that do not usually include the world view, experiences, and knowledge and wisdom of the indigenous people, but it is also found in the world within which indigenous students live. This means that everything around the student's environment can be a source of relevant learning (Dewi, 2014: 21) as well as various aspects of local wisdom.

\section{English Language Learning and Information Technology}

Government's act No. 32 of 2013 concerning national standards for primary and secondary education Article 19 Number (1) states that learning at the education unit level must be held interactively, inspirationally, fun, challenging, and motivates students to actively participate and can provide sufficient space for the creativity and independence of students according to their talents, interests and physical and psychological development. Learning media is seen as a means to realize the implementation of learning that is demanded by these regulations.

In light of the development of information and communication technology and to meet the demands of National Standards of Primary and Secondary Education, namely creating pleasant, challenging, creative, training atmosphere for students to become independent, it is 
deemed necessary to integrate information and communication technology into learning tools, including visualized materials with a high technology in the context of local wisdoms. Then, in accordance with a needs-analysis of the research conducted by Prismayudi (2012) that the availability of information technology facilities in schools, such as in junior high schools has not been maximally utilized by the teachers, so they really need help to empower the facilities they must support the smooth learning process to achieve maximum targets in the framework of implementing the Curriculum 2013. Therefore, the use of information technology tools for English learning materials of local wisdoms and processes based on local wisdom, is expected to enliven the atmosphere and internalize learning messages that contribute in shaping the character of students.

\section{Study on Local Wisdoms-Based English Language and English Material Curriculum Design}

\subsection{English Language Varieties}

English has developed into some varieties throughout the world which is known as World Englishness (Teachers of English to Speakers of Other Languages-TESOL, 2008, Yamuna Kachru and Smith, 2008). TESOL is an association of English teachers for speakers of other languages. Varieties in this case include the diversity of standard English spoken in Anglophone countries, such as; United States, United Kingdom, Canada, Australia, New Zealand, South Africa, and also local varieties in various parts of the world, such as; India, Africa and the Caribbean and Indonesia. The three concentric circles of language, namely the inner circle referring to a language taking shape and it was spread across the world in the first diaspora. In the process of transplantation of English of England speakers carried out the language to Australia, New Zealand, and North Africa. The inner circle represents the historical base and the sociolinguistic base of an English to the other countries where English used as a primary language; USA, UK, Australia, New Zealand, Ireland, Anglophone Canada, and some Caribbean territories. The outer circle of English spread the language through the imperial expansion by Great Britain in Asia and Africa. In this circle, an English is not spread as a native language, but a lingua franca between ethnic and language groups. The last, the expanding circle that encompasses some countries in which an English does not play the historical role as well as governmental role, but it is widely used as a medium of a global communication.

The concept of variety of English itself is rooted in social reality and the function of language users in certain contexts. In line with the global grouping of the countries, as the following figure can be described as in Figure 3: 
Figure 3: The Three Circles of Kachru's English Varieties, Kachru's; 1992 in English in the World (Seargean \& Swann, 2012)

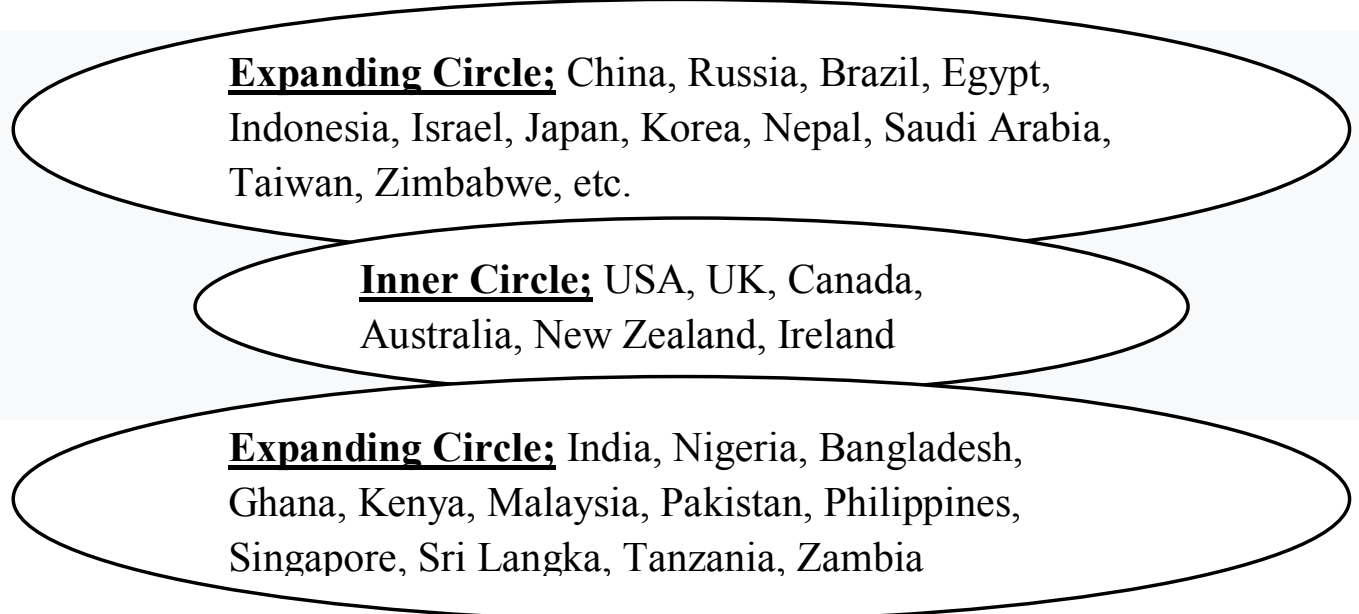

As a global association, TESOL (2008: 1) considers the rights of every language, collaborates in a global community, and respects diversity and multiculturalism, so that in this case, TESOL encourages and appreciates all varieties of English, including dialects, creoles and English language varieties in the world.

\subsection{Local or Indigenous Wisdoms Based English Language Learning}

Then in connection with English learning by integrating the values of local wisdoms in the curriculum, as Rattanaphumma, R. (2006) in an international conference proceeding, examines the problem of community-based English learning with the title 'Community-Based English Course in Local Perspectives' at Chulalongkorn University, Thailand. Then he showed that motivation, experiential learning (experience) and collaboration play an important role in the learning process of language and culture. He also elaborated the significance of the local perspectives in the design of English materials, besides local resources can also be used and mobilized for long-life learning.

Putrasulung (2012) further explained the urgency and steps taken to optimize the contents of local wisdoms in learning German for Indonesian learners, where the study was directed at examining Indonesian local wisdoms in general and elements of wisdom in German culture. Thus he delivered several types of activities in the teaching and learning process of German that can be used to deliver local wisdom contents to learners.

Anggraini, P. and Kusniarti, T. (2015) investigated the local content of learning material in Indonesian textbooks for senior high schools. According to them, this preliminary study was used as a basis for having richness in character in learning material design. The result of research presented in English and published in the Journal of Education and Practice. In their description, Indonesian language learning material that contains local wisdoms does not only enrich students with general knowledge, but also form the strength of their character as well. Regarding to language learning content, the preparation of the text contains more content of local wisdom that contributes to the development of students' insights and knowledge about diversity in Indonesia 
Wangkaewhiran (2012) examines the issue of local wisdom content as a model of learning management in the ASEAN by doing case studies in schools in the Chachoengsao Muangthai. This research was conducted by a number of teachers, through conducting an opinion gathering, both towards teachers and local students. Thus the results show that the teachers of each department of the schools have taught local wisdom content with different types and times in each semester. In a further explanation that there are only two of the eight departments, the Thai language department and the foreign language department that can apply all the ten types of local wisdom content. There are four models of learning management of ASEAN-based local wisdom content that have been developed in this study with a so high level of consistency and accuracy. In addition, the results also showed that teachers and students expressed satisfaction with the good learning outcomes released by the Educational institution by using such a model, and it also suggested that each school should prepare the model and other stakeholders in order to face the community ASEAN 2015. The author is one of the participants in The Asian Conference on Education 2012 which was published in the Official Conference Proceedings, Osaka Japan.

The limitation of the curriculum development concept and the English language learning design for secondary school levels that has not accommodated the local potentials optimally and integratedly through the use of information technology in the learning process. This is because of the condition of human resources irrespective for global issues, EFL learning is not accommodating the local potentials, and the linguistic problems in the context of exploring the local wisdoms' potential. Furthermore, these problems can be overcome by integrating the potential of local wisdoms into English learning materials. In the aspect of learning methods, the approach to be implemented is by referring to the changes or a revised edition of Curriculum 2013 scientifically through observing, asking, trying, and reasoning. The approach emphasizes optimizing the development of aspects of learners' potential (junior high school students) such as; development of language competence, understanding the meaning of texts, the ability to text arrangement according to the rules in accordance with situations and conditions, and oral language exposure. The aspect of the potential development of the learner's will be integrated in every subject, including English with local wisdoms by utilizing information technology aspects in learning process.

The strategy in translation process of a language from the source language (Indonesian/Regional) to the target language (English) through Diffusion and Adaptation approaches. Diffusion and adaptation mean the spread and adjustment of English with an international scale so it would be diversified, both American English and British English as imput. In the process of diffusion and adaptation, furthermore in the context of regional and local sociocultural, enculturation occurs (the process of internalizing values and norms) and indigeneousity (indigeneousity process) which produce local and regional English characteristics varieties as output. 
Figure 4: The Strategy of Language Translation, Adapted from English as Multicultural Language in Asia (Honna, 2005).

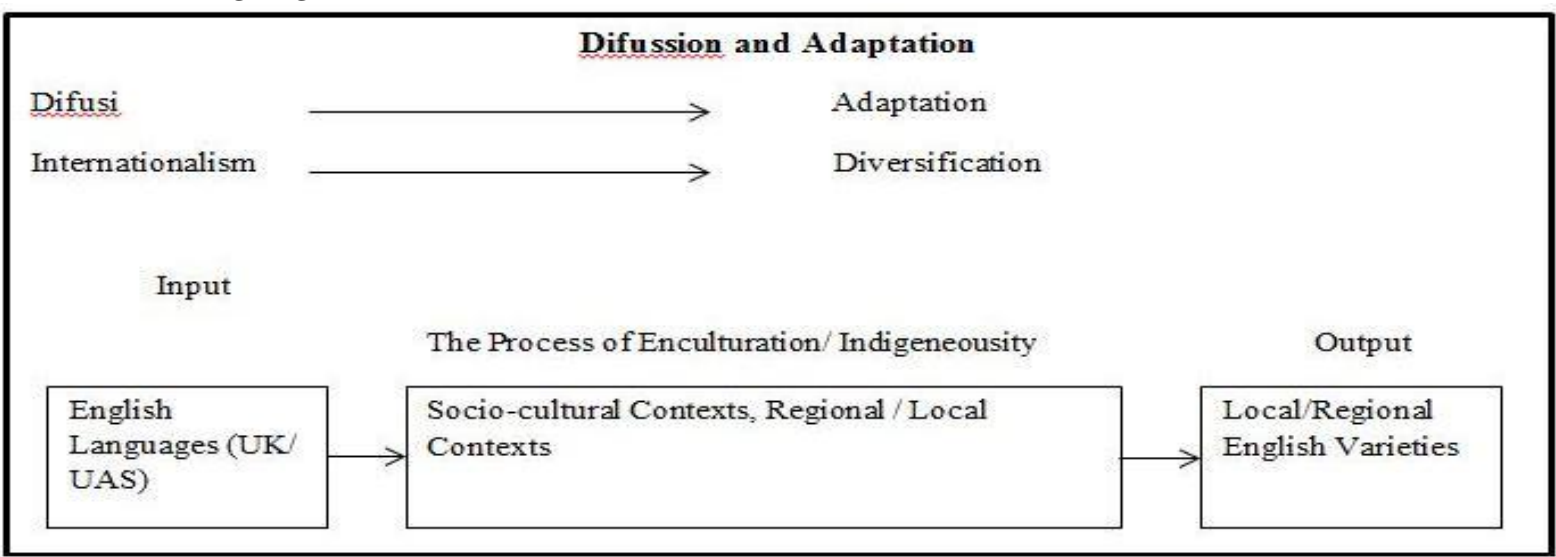

\section{Conclusion}

English can be both as a native tongue and as a lingua franca. The most significant model of English spread across the worlds might have yielded the significant English varieties. What are so-called an English varieties could have been as the result of transplantation of England English speakers to the other English countries lead the Kachru's three concentric circles; the inner circle, the outer circle, and the expanding circle. The emergence of English varieties (World Englishness) is as the result of the diversity of speakers having different L1 geographically and demographically. Another aspect of English studies is the role of local wisdoms having the potentials to produce linguistic elements shows that the existence of the indigenous wisdoms (local values) indicates the potential varieties of English. Local English varieties must properly be considered as well as developed in case of an English curriculum for Secondary High School which is adapted to Curriculum 2013. This Local curriculum development is categorized into expanding circle as the character of English variety of the world Englishness.

The significance of local wisdoms to ICT -based English materials development. Local wisdoms-based English materials-development can foster the language learners' independence and creativity hence those materials are purely driven from what they experience around their environments (indigenous values). Local wisdoms are as the sources of knowledge where these are defined as in local knowledge, folk knowledge, people's knowledge, and traditional sciences. These kinds of knowledge are passed from a generation to generation stored in cultures in various forms; tradition, customs, folk stories, folk songs, folk drama, legends, proverbs, and myths. Thus these can be as potential resources of learning in case they can effectively bring up the indigenous knowledge alive for the students. Thus the consideration of local knowledge as English learning sources can produce creativity, independence and intervention. Moreover the emergence of English variety as the consequence of the globalizing English as the key issue of the plurality of English lead the cross-cultural English as well as the global contextualization as English is used an international means of communication. 
By designing English language learning which is based on cross-cultural approach and global contextualization, a writer suggests material designers and material writers consider a new status of English (local English). Language and the other related elements are the potential elements of local wisdoms which can be called as a black box which is to be revealed for becoming English learning materials. The use of technology is as a part of ICT learning principles. Technology is applied as learning means meeting the demands of National Standards of Primary and Secondary Education by creating pleasant, creative, challenging atmospheres.

\section{References}

Bolton, Kingsley. (2003). Chinese english: A sociolinguistic history. New York; Cambridge University Press.

Crystal, D. (1997). English as a global language. Cambridge: Cambridge University Press.

Dewi, Ni Luh Putu, E.S.(2014). Pelatihan pengembangan media animasi untuk pengajaran bahasa inggris SMP di Kecamatan Buleleng. Universitas Pendidikan Ganesha. Bali.

Honna, Nobuyuki. (2005). English as Multicultural in Asia and Intercultural Literacy. Intercultural Communication Studies; Vol.14 ( 2).

Jenkins, J. (2003b). World Englishes: A resource book for students. London: Routledge.

Kachru, B., Kachru, Y., \& Nelson, C. L. (2006). The handbook of world english. Oxford, England; Blackwell.

Mahboob and Tilakaratna. (2012). Teaching of english as second language. a principlesbased approach for english language teaching policies and practices. Tesol International Association. California. USA.

Prismayudi, R, K.(2012). Developing genre based animation media for teaching speaking in the seventh grade students of SMP N 1 Sukasada in the Academic Year 2011/2012. Skripsi. Undiksha.

Rattanaphumma, Ratchaporn. (2007). Issues an Implication of English for Teaching English in the Expanding Circle. Jurnal.University of Thailand. 18- 20.

Seargean P. dan Swann, J. (2012). Worlds of English, English in the World, History, Diversity, Change. The Open University.Routledge. New York.

Wagiran. (2011). Pengembangan Model Pendidikan Kearifan Lokal dalam Mendukung Visi Pembangunan Provinsi Daerah Istimewa Yogyakarta 2020 (Tahun Kedua). Fakultas Teknik, Universitas Negeri Yogyakarta. Jurnal Penelitian dan Pengembangan, III/3/ISSN 2085-9678. Hlm. 85-100.

Wangkaewhiran, Thipwimol. (2012). Development of Local Wisdom Learning Management Model of ASEAN Focus School: A Case Study in Thailand. The Asian Conference on Education 2012. Osaka. Japan. Official Conference Proceedings 